\title{
Foreign Language Writing in the Context of Modern Language Education in Non-Linguistic Majors
}

\author{
Irina Melikhova
}

South Ural State University (National Research University), Russia, melihovain@mail.ru

Anna Skorobogatova

South Ural State University (National Research University), Russia, anna.skorobog@mail.ru

The article is devoted to the actual problem of teaching students of non-linguistic majors to write in a foreign language. The purpose of the study is to assess the students' level of written language competence. In 2018 and 2019, the Academic Competition (AC) of foreign languages" Prometheus" was held at South Ural State University (SUSU). In the qualifying round of the AC, students of 1st and 2nd courses took part: in 2018 - 1,300 people, in 2019 - 1,600. Participants who scored more than $60 \%$ of the correct answers were allowed to the "Writing" section. The essay was chosen as the format to test written speech. The number of students who wrote an essay in 2018 was 186, in 2019 - 294 of the total number of participants. Evaluation of written works was carried out on the basis of the requirements to the similar task in the international IELTS exam. 4 criteria were assessed: Task response, Coherence and Cohesion, Lexical resource, Grammatical Range and Accuracy. The analysis of the participants' written works has revealed that the most difficult thing in creating written speech works in a foreign language is the ability to express and argue one's own opinion. The study examines the psychological and pedagogical features of writing in a foreign language. The authors formulate guidelines for teaching students to write in a foreign language.

Keywords: non-linguistic major, higher education, foreign language, writing skills, peculiarities of foreign writing, teaching foreign language guidelines

\section{INTRODUCTION}

The process of globalization in higher education, the development and expansion of international contacts in all spheres of human activity open up tremendous opportunities for students and graduates of Russian universities. These changes require a modern specialist to speak a foreign language at a fundamentally new level. In this regard,

Citation: Melikhova, I., \& Skorobogatova, A. (2020). Foreign Language Writing in the Context of Modern Language Education in Non-Linguistic Majors. International Journal of Instruction, 13(2), 151-164. https://doi.org/10.29333/iji.2020.13211a 
demands to the quality of foreign language teaching are increasing. The main requirement is the need to bring the content and methods of teaching a foreign language to the practical needs of students - future highly qualified specialists, who must possess both professional knowledge and language skills.

The main purpose of teaching a foreign language in non-linguistic majors is to acquire the communicative competence. Its structure is multicomponent, each of them implies mastering one or another communicative technique, but the educational process is still reduced to learning the main language skills: speaking, listening, writing and reading. When teaching foreign language communication its oral form - speaking is singled out. The concept, that the written language has a supporting role, has become quite widespread. Today the situation has changed, as evidenced by the increased interest of researchers in various aspects of teaching writing. It is no coincidence, as writing a letter and essay has become an integral part of the Unified State Exam (USE) in high school.

Foreign writing teaching is an important component of foreign languages educational programs for different categories of university students. For example, in the programs for masters and graduate students, the research component is highlighted, which involves the preparation and editing of scientific publications, the presentation of research results in the form of scientific reports, articles (Melikhova, 2018; Skorobogatova, 2017; FSES HE, 2010; FSES HE, 2014). It should be noted that, although the presentation of scientific reports is oral, the text of the speech is a written fixation of the stated content.

As for the graduates of both linguistic and non-linguistic specialties, for them the continuation of education and the attempt to find employment abroad have become a fairly common practice. To do this, you must pass one of the international exams, for example, International English Language Testing System (IELTS) or Test of English as a Foreign Language (TOEFL) etc. Writing tasks are in both exams. For example, when passing IELTS, you need to write an essay, of an academic level - describe charts or formulate written conclusions based on the presented information.

Finally, grant applicants seeking internships at foreign universities should attach a justification with a brief statement of their professional and scientific interests and achievements to their application for a grant.

Since 2010 SUSU has provided an opportunity for its students to get additional education within the career broadening course which provides an opportunity to be plunged in the activities connected with the application of foreign languages skills. Graduates have to write a report in a foreign language, and then defend the thesis.

Thus, the objectives of teaching to write in a foreign language for different categories of students involve the formation of the ability to generate a coherent text of various sizes and genres.

Unfortunately, studies show that a significant part of university graduates do not have the ability to correctly express their thoughts in writing in a foreign language (Sabanova, 2007; Chuikova, 2005). 
According to the available statistics provided by the British Council, up to $50 \%$ of Russian-speaking applicants for international language certificates do not receive them due to numerous and serious mistakes in writing tasks (Avhacheva, 2016).

Professional written foreign language communication has become an integral part of the activities of any scientific institution or industrial enterprise. With the continuing increase in importance and value of oral communication today, almost $80 \%$ of information exchange in the field of science and technology, both within organizations and between them, is carried out using written speech (Smirnova, 2015; Vassilaki, 2017).

Foreign writing teaching in the system of university training is relevant not only in itself, but can contribute both to the formation of other important competences and to the process of mastering a foreign language as a whole. The tasks to be solved while teaching writing include the development of students' speech-thinking skills and the ability to formulate ideas in accordance with the written style, the expansion of knowledge and horizons, the mastery of culture and intellectual readiness to create written works of speech. Full possession of written language is becoming one of the key characteristics of a high-class employee who is able to function not only in the national labor market, but also successfully integrates into the global highly developed professional community, where foreign language written speech along with professional components acts as a means of realizing professional and personal ambitions.

Issues of writing training are widely covered in the works of foreign researchers "Writing is one aspect of language that has always posed problems among the other language skills (i.e. reading, speaking and listening). It is not only to the learners who are learning it, but also to the teachers who are teaching it" (Durmuşoğlu Köse et al., 2019).

Some surveys of foreign colleagues are aimed at studying the methods of assessing writing skills; in particular, they investigate portfolio method (Uçara \& Yazıc1, 2016). Also scientists focus their attention to the use of lexical bundles for creating and writing essays (Kazemia, Katiraeib \& Rasekh, 2014). Besides mentioned above there are other works that indicate the importance of special tasks while writing skills practice (Rus, 20 16), and proposals for the development based on the analysis of multi-genre structures (Casañ-Pitarch \& Calvo-Ferrer, 2015).

All these works demonstrate the necessity to address the issues of teaching foreign language writing.

The target audience of our research is students of non-linguistic majors studying foreign language according to the discipline «Foreign Language». The number of hours provided by the curriculum is not enough for the successful development of written skills. Therefore, it is necessary to identify the weaknesses of the formed skill and choose the most effective methods for its development. 


\section{METHOD}

\section{Research Design}

To assess the level of communicative competence in writing, the SUSU organised the AC in foreign languages in 2018 and 2019. Over the years, every year in Russia is devoted to a specific topic or event. The purpose of this tradition is the necessity to pay public attention to important issues in the life of the country. 2018 was declared the year of ecology by the President of the Russian Federation, 2019 - the year of volunteering. This determined the theme of the AC. The Methodical Commission outlined the theme of the 2018 Olympiad as "Our eco-future: is it there?"; The theme for 2019 is "Volunteer activity: real people, real affairs". All the tasks were created according to the listed topics.

The following tasks were included in the program of the AC: lexical and grammatical test; understanding of the written text (reading); understanding of the oral text (listening); compilation of an essay on the video (writing) watched; making presentations on a given topic (speaking) and country study.

The Academic Competition was organized in two stages: the qualifying stage was held remotely and involved electronic testing and writing an essay, after watching the video file. To register and complete assignments for the qualifying round, 2 weeks were allotted from February 18 to March 3, 2019.

The final stage was held in full-time during the period from April 1 to 10. Its aim was to check the level of proficiency in oral foreign language speech. Therefore, participants were invited to prepare a presentation on the topic.

The realization of the task was achieved through modelling of an Academic Competition in foreign languages in the course management system (CMS) Moodle. The support of the Institute for Open and Distance Education of South Ural State University allows optimizing the procedure for registering, identifying, verifying the work significantly and create comfortable conditions for the participants.

In composing the set of tasks for the $\mathrm{AC}$, we took as a basis the recommendations proposed by Ter-Minasova (2011) were taken as a basis. Assignments should be of a problem-search nature and reveal the creative potential of the participant. Texts must meet the following requirements: to be modern, thematically and socio-culturally adequate. The language complexity of the texts should correspond to the chosen level of complexity and the task set, and the skill being tested. It is necessary to pay attention to the correctness of the wording of all the tasks of the qualifying round: the wording should be simple and accessible, and the units to be checked should have communicative value.

\section{Participants}

The target audience of the Academic Competition is students of the 1st and 2nd years undergraduate and full-time courses in non-linguistics majors. In 2018, 1,300 students 
took part in the qualifying round, and in 20191600 people. The number of participants in 2019 increased by $23 \%$. This is due to the fact that the event was granted the AllRussian status and some changes in format were carried out. 500 students from 12 universities of Russia became participants of the AC: Tomsk SU (3\%), TomskSPU (1\%), Chelyabinsk State University (10\%), Bashkir State University (47\%), Bashkir SPU (9\%), Omsk SU (9\%), Kazan FU (3\%), Khanty-Mansiysk SU (2\%), Dimitrovgrad SU (1\%), Samara SU (2\%), Ulyanovsk SU (12\%), Yekaterinburg SU (1\%).

\section{Instruments}

Essay was suggested as the means of evaluating students' writing skills. The essay was available only after the successful completion of assignments for the qualifying round and a set of $60 \%$ correct answers. The students were offered a video file that can be viewed 2 times, after which they should write an essay on the topic presented in the video. The task execution time is 1 hour and 45 minutes.

When choosing a video, we proceeded from the following provisions: the complexity of the video should correspond to the chosen level of proficiency in a foreign language; subjects are interesting for students; the speaker's speech is clear, the pace of speech is natural; video duration no more than 3 minutes; a small number of unfamiliar words may be contained in the speaker's speech, ignorance of which does not prevent understanding of a monologue or dialogue, and writing an essay; the topic of the essay should not initiate only the presentation of the watched video, its purpose is to encourage participants' reflection. In 2018, 186 people wrote essays, which accounted for $14 \%$ of the total number of participants, in 2019 - 294 people (18\%).

\section{Data collection}

The essays have been assessed by the teaching stuff of the foreign languages department within 7 days in accordance with the criteria provided of the international IELTS exam.

Criteria:

1. Task response (If the student's answer addresses all the points in the question. If the student provides a balanced argument and support his ideas with evidence and examples. If all the ideas are relevant to the question. Whether the participant follows the necessary volume of the text (at least 250 words).

2. Coherence and cohesion (If the writing is easy to understand. Whether the ideas are well organised and clearly linked).

3. Lexical resource (If the participant uses a wide range of vocabulary accurately and effectively).

4. Grammatical range and accuracy. (Whether the student uses a wide range of grammatical structures accurately and effectively.

Based on the criteria, a system for evaluating the written language of participants was obtained. Each criterion was awarded 5 points, based on the maximum number of points 20. All works were checked with the anti-plagiarism system. When plagiarism was 
detected, the works were canceled. Over the 2 year period there were $5 \%$ of works with high percentage (up to $50 \%$ ) of borrowings.

\section{FINDINGS}

The ultimations of the analysis of the completed AC's tasks showed that the level of formation of each component of communicative competence is different.

The results of the tasks of the qualifying round are displayed in Table 1.

Table 1

The Average Percentage of Assignments for the Qualifying Round of the Academic Competition

\begin{tabular}{llllll}
\hline $\begin{array}{l}\text { Tasks of the qualifying } \\
\text { round }\end{array}$ & Reading & $\begin{array}{l}\text { Lexical- } \\
\text { grammatical test }\end{array}$ & $\begin{array}{l}\text { Country } \\
\text { study }\end{array}$ & Listening & Writing \\
\hline $\begin{array}{l}\text { average \% of assignments } \\
(2018-2019)\end{array}$ & 84 & 63 & 48 & 56 & 37 \\
\hline
\end{tabular}

The most stable skills are formed by the participants in the reading section. Tasks for listening and the lexical-grammatical test for most of the participants were not difficult. The analysis of the results of the "Country Study" section showed that further serious work is needed to study historical, cultural and geographical realities. The formation of the skill of writing is one of the most serious problems in teaching a foreign language; only $37 \%$ has successfully completed this task.

Table 2

The Results of the Essays, \%

\begin{tabular}{llll}
\hline Year & 2018 & 2019 & Overall for 2 years, \% \\
\hline Task response & 38 & 41 & 39,5 \\
Coherence and cohesion & 68 & 67 & 67,5 \\
Lexical resource & 74 & 78 & 76 \\
Grammatical range and & 65 & 67 & 66 \\
accuracy & & & \\
\hline
\end{tabular}

From the table above it is clear that when creating a written work, the lexical resource and the ability to construct one's logical reasonably correct argument are particularly difficult. A grammatical organization of the statement and the need to state the problem at the beginning of the written work, not repeating the wording of the task, but using synonymous means make the written task challenging for the students. The organization of the text, namely the division of the text into paragraphs and the use of means of logical communication, caused complexity in more than half of the participants. Spelling and punctuation are the highest points among the 4 tracked criteria. The following is a detailed analysis of the written work. 
Table 3

Typical Mistakes in Written Works

\begin{tabular}{|c|c|c|}
\hline Criteria & Requirements & Typical problems \\
\hline $\begin{array}{l}\text { Task } \\
\text { response }\end{array}$ & $\begin{array}{l}\text { The essay should fully } \\
\text { address all parts of the } \\
\text { task, present a totally } \\
\text { developed position in } \\
\text { answer to the question } \\
\text { with relevant, fully } \\
\text { extended and well } \\
\text { supported ideas. }\end{array}$ & $\begin{array}{l}\text { - inability to formulate a problem at the beginning of a writing } \\
\text { work (repetition of the of the task's statement); } \\
\text { - the absence of a detailed argument or its inconsistency with the } \\
\text { stated thesis (opinion); } \\
\text { - repetition of the argument in the expression of his and others' } \\
\text { opinions; } \\
\text { - incorrect formation of counterarguments; } \\
\text { - the desire to replace their own reasoning on the proposed } \\
\text { problem and a changing of the topic; } \\
\text { - use of individual memorized phrases or ready text on a similar } \\
\text { topic, the presence of works with identical content; } \\
\text { - inability to draw conclusions at the end of work; } \\
\text { - failure to comply with the required volume; } \\
\text { - substitution of one genre of written utterance by another. }\end{array}$ \\
\hline $\begin{array}{l}\text { Cohe } \\
\text { and }\end{array}$ & $\begin{array}{l}\text { The essay should have } \\
\text { cohesion in such a } \\
\text { way that it attracts no } \\
\text { attention and skillfully } \\
\text { manage paragraphing. }\end{array}$ & $\begin{array}{l}\text { - absence of the topic sentence in the beginning of each part of } \\
\text { the essay; } \\
\text { - logical errors, the divergence of the author's point of view in } \\
\text { the main content and output; } \\
\text { - misdivision of the text into paragraphs; } \\
\text { - violation of the logic and coherence of the text; } \\
\text { - the absence or misuse of logical communication. }\end{array}$ \\
\hline $\begin{array}{l}\text { Lexical } \\
\text { resource }\end{array}$ & $\begin{array}{l}\text { The essay should have } \\
\text { a wide range of } \\
\text { vocabulary with very } \\
\text { natural and } \\
\text { sophisticated control } \\
\text { of lexical features; } \\
\text { also it has a rare minor } \\
\text { error which occurs } \\
\text { only as slips. }\end{array}$ & $\begin{array}{l}\text { - monotony of vocabulary (repetition of the same words and their } \\
\text { derivatives); } \\
\text { - inability to find synonyms and antonyms; } \\
\text { - misuse of lexical items; } \\
\text { - presence of lexical errors affecting the understanding of the } \\
\text { content; } \\
\text { - misspelling. }\end{array}$ \\
\hline $\begin{array}{l}\text { Grammatical } \\
\text { range and } \\
\text { accuracy }\end{array}$ & $\begin{array}{l}\text { The essay should have } \\
\text { a wide range of } \\
\text { structures with full } \\
\text { flexibility and } \\
\text { accuracy. }\end{array}$ & $\begin{array}{l}\text { - monotony of grammatical structures (primitive simple } \\
\text { sentences, the inability to use the wealth of verb forms of the } \\
\text { English language to express their thoughts; } \\
\text { - inability to use complex grammatical structures necessary for } \\
\text { this type of work, e.g. complex object or complex subject; } \\
\text { - misuse of grammatical structures; } \\
\text { - the presence of grammatical errors (violation of word order, } \\
\text { incorrect use of indefinite pronouns, uncountable nouns); } \\
\text { - misuse or punctuation marks; } \\
\text { - use of incorrect prepositions after verbs and / or adjectives. }\end{array}$ \\
\hline
\end{tabular}

\section{DISCUSSION}

The paper analyzes the level of proficiency in foreign language written speech of students of $1^{\text {st }}$ and $2^{\text {nd }}$ course of non-linguistic specialties. The object of attention was the "Writing" of Academic Competition section, which involved writing an essay after watching the video. Based on the analysis of written works, the authors identified typical mistakes made by students while creating an essay. Writing is difficult, and indicates a lack of skill in its formation. From the 4 evaluation criteria, arguing one's own opinion is the most difficult for students. 
We single out the essay as a way to evaluate writing skills, since it plays an important role in the development of a competent specialist. The essay performs several important functions. First of all, creating an essay, the student learns to logically express their own thoughts. Strict organization, following the topic, the use of linking words and expressions, all these ultimately contribute to the overall picture of the student's education. In addition, the essay, in our opinion, may be the form of work that would prepare students for writing of more complex genres - a report for a public speech, an abstract, a scientific article etc.

Testing writing skills is a part of universal world practice in the field of higher education along with such traditional works as term papers, dissertations, graduation theses. Increased attention and rigor to plagiarism today, as well as the ease of plagiarism testing, force the student to compose text independently or use the ability to paraphrase and, therefore, have a good knowledge of using various grammatical structures, as well as possessing a good vocabulary to use synonyms.

The format of the competition was chosen for several reasons:

- our form combines several information media (audio, video, text), which allow you to check all types of speech activity skills. In addition, the Academic Competition can be attributed to innovative and modern teaching technologies along with such methods as the problem and project training method, gaming technology, the creation of problem situations. One of the main goals of which is to awaken students' interest in the discipline and self-education under study, that is, to increase motivation (Vishnyakova, 1999; Jeffrey \& Craft, 2010; Heaysman \& Tubin, 2018; Thoonen et al., 2011).

- the number of participants in the qualifying stage is unlimited, the AC allowed to test a fairly large number of students (2,900 people in a two-year period, 500 people wrote the essays);

- students have the opportunity to work in an individual mode (everyone performs tasks autonomously at a convenient time);

- assessment of tasks of the AC is carried out automatically (because tasks have a test character), and therefore objectively;

- the tutor does not spend time on checking assignments;

- the effectiveness of writing an essay depends on the preliminary work, it involves the implementation of a variety of training tasks (Chernukhina \& Chernukhin 2015; Likhacheva, 2017). The previous tasks of the Academic Competition performed before watching a video (working with text, listening, performing a lexical grammar test) can be considered as a preparatory stage.

- AC, as an educational event, is the accumulation of innovative experience not only for organizers, but also for students who have the opportunity to take part in the competition twice, since the AC "Prometheus" in foreign languages is held for students of nonlanguage majors of the 1 st and 2 nd courses. 
The qualifying round results were provided to the teachers of the listed universities on their request, the purpose of which was to analyze the existing problems and make adjustments to the work on the discipline "Foreign Language".

Analyzing the mechanisms of types functioning of speech activity, psychologists and methodologists come to the conclusion that there are similarities and differences between writing and speaking. In that way, Galskova (2000) notes the similarity of the mechanism of internal speech, i.e. internal plan of the future text. In the process of writing, a transition is made from a word, pronounced out loud or to oneself, to the word apparently. When speaking we see the transition from the word uttered to himself, to the word spoken aloud.

Without denying the similarities between writing and speaking, Solovova (2002) identifies a number of differences between them. A written statement is a monologue, built quite fully. In connection with this, a written piece contains additional information, definitions, specifying signs. Information should be presented consistently and logically, clearly and concisely, since there will be no possibility to change or repeat something. Therefore, written speech is carefully thought out.

According to Passov (2000), written language, both in its origin and in its psychological structure, differs from oral speech, and a conscious analysis of the means of its expression becomes the main psychological characteristic of written speech. Gromova (2010) explains the difficulties in constructing written works by the fact that during oral communication, direct verbal interaction of interlocutors occurs, which allows them to correct their position taking into account the reaction of the others. In addition, it can be complemented by a variety of non-verbal means that convey certain aspects of the communication situation. A written speech is characterized by its greater awareness, due, on the one hand, to the distantness of written communication, and on the other, by its intentionality. The consequence of this is not only a careful selection of lexical material and grammatical structures, but also the need to consider the structure of the written message. Thus, when teaching written foreign language communication, it is necessary to take into account all the features. The difficulties of teaching a foreign language writing skills can also include the dominance of the communicative approach in teaching a foreign language for several decades, which does not involve the development of writing speech (Kitaigorodskaya, 1986; Passov, 1985). As a result, students write texts that are not too cohesive and have little meaning. According to the researcher Avramenko (2012), writing speech training in a foreign language causes difficulties due to the lack of formed written language skills in their native language.

More particular reasons for the state of teaching foreign language writing in higher education institutions that do not meet modern requirements are a lack of study time, a lack of effective learning technologies, a lack of teaching materials, and teaching aids. Very little time is given to the analysis and correction of written works, and as a result, students have great difficulty in writing texts of any nature and genre.

Russian methodists differently understand the goals and objectives of writing speech training of FL, putting forward various requirements for the final result. For example, 
write a personal letter, a greeting card, fill out a form in a hotel, and also make extracts of the necessary information from the text (Sysoev \& Evstigneev, 2010). According to Solovova (2002), the goal of writing speech training is to develop the ability to write in any foreign language on the same topics that an educated person can write in their native language. The question of what writing texts should be taught, the author decides in terms of preparing for the delivery of various kinds of written exams. According to Milrud (1998), the purpose of teaching writing is to form pupils' written speech competence, which he defines as the possession of written characters, the content and form of written works of speech.

The analysis of educational programs in the foreign language discipline and modern conditions of student teaching led to the conclusion that the end result of teaching foreign language writing is the ability and willingness of students to carry out foreign language written communication in the field of personal and professional communication, applying knowledge, skills, strategies and experience with a foreign language text, taking into account the construction of written statements in the culture of the language being studied.

Exercises for teaching writing skills can be divided into 3 types: reproductive (preparatory), reproductive-productive and productive (creative). Preparatory exercises are mainly language- training exercises aimed at mastering terms, phrases, and collocations. At this stage there is a training of lexical and grammatical material at the level of words and phrases. It is advisable to suggest the following exercises: fill in the blanks in the sentences; write down the key words; title paragraphs of the text; make a thesis to each semantic part of the text; make a retelling plan. The next stage is aimed at further improvement of language skills and development of speech skills. At this stage, fewer supports are offered compared to the previous one. Students learn to select, vary, and combine grammatical and syntactic structures. The work is at the level of the sentence and the text: answer the questions to the text; translate sentences; combine several sentences into one; broaden or shorten sentences by pattern; transform direct speech into indirect speech and vice versa. The creative stage is represented by productive exercises in which conditions are created that are as close as possible to natural communication. The following tasks, in our opinion, are of interest: restore the beginning and end of the story; restore the dialogue on individual cues; change the type of the text (monologue for dialogue; dialogue for monologue); make a letter according to the proposed plan. Translation from a foreign language into Russian and vice versa is also important when forming written speech activity (Mirolyubov, 2011). Students learn to encode and correctly decode the received information (Rogova, 2010).

We formulate recommendations for the teaching of writing:

- the gradual formation of skills in written foreign language speech;

- communicative orientation and ability of educational material to serve as a basis for generating new written texts;

- problematic supply of material; 
- authenticity of educational materials;

- accessibility for students at the language level;

- socio-cultural richness of educational and speech material;

- organization of trainee speech activity on the basis of the lexical, grammatical phonetic features of the language being studied, i.e. to ensure their inseparable connection in the communication process;

- teaching of writing should be based on knowledge of the genre features of the written works created: the structure and organization of the work, the mechanism for constructing argumentation, the stylistic differences of the genre under study;

- interconnected teaching of all types of speech activity;

- when developing language training programs for undergraduate, graduate and postgraduate students, it is necessary to take into account the standards and criteria for evaluating written speech that are adopted in the current system of international exams.

These components will help to reach a qualitatively new level of proficiency not only in the written form of communication, but also in any foreign language as a means of intercultural communication.

In this regard, one of the ways to overcome this problem is to develop a methodological model of training, including goals, content, exercise system and teaching aids, aimed at the formation of communicative competence in the construction of a written text. Methods of teaching written foreign language speech should be developed taking into account the peculiarities of writing and the communicative needs of students.

Now, a set of exercises is being developed for teaching written foreign language speech and tasks for controlling and self-monitoring the formation of a written skill. Since the complex of exercises in itself cannot provide the desired teaching outcome, in the future it is planned to develop a learning and teaching support kit aimed at developing skills and improving communicative competence in writing.

\section{CONCLUSION}

In recent years, the role of writing in teaching of a foreign language has gradually increased. Writing penetrates into professional and interpersonal communication, new educational standards for secondary and higher education and the system of language control determined by them reflect the need for teaching written language. Therefore, it is necessary to revise the approach to the teaching of writing foreign language speech and to improve the methodology of teaching writing.

Writing a text is a complex process that requires the simultaneous use of many skills. These skills need to be formed and developed. And the task of the teacher is to select the most effective approaches and exercises for the successful solution of this task.

The research topic is promising in the search for solutions to the problems of teaching written communication between students of both non-linguistic and linguistic majors. 


\section{ACKNOWLEDGEMENT}

The work was supported by the Act 211 of the Government of the Russian Federation, contract № 02. A03.21.0011.

\section{REFERENCES}

Avramenko, A.P. (2012). Cognitive and verbal difficulties of developing the skills of foreign language writing in English. Foreign languages at school, 11, 50-54.

Avkhacheva, I.A. (2016). The main and related tasks of teaching writing in a foreign language in different target audiences. Philology. Questions of theory and practice, 4(58) part 3, 165-169.

Casañ-Pitarch, R., \& Calvo-Ferrer. (2015). Developing writing skills in the classroom: A corpus-based analysis of multi-genre structures. Procedia - Social and Behavioral Sciences, 198, 74-83.

Durmuşoğlu Köse, G., Yüksel, İ., Öztürk, Y., \& Tömen, M. (2019). Turkish academics' foreign language academic literacy: A needs analysis study. International Journal of Instruction, 12(1), 717-736.

Federal state educational standard of higher professional for 020100 Chemistry (qualification "Master"). (2010), from http://fgosvo.ru/uploadfiles/fgos/31/20110318161219.pdf.

Federal State Educational Standard of Higher Education Higher Education Level Training of Higher Qualification Personnel Direction of Training 04.06.01 Chemical Sciences (2014), from http://fgosvo.ru/uploadfiles/fgosvoaspism/040601.pdf.

Galskova, N. D. (2000). Modern methods of teaching foreign languages: A teacher's guide. Moscow: ARC - TI.

Gromova, N. M. (2010). Business communication in a foreign language: teaching methods: a manual for universities. M.: Master: Infra-M.

Heaysman, O., \& Tubin, D. (2018). Content teaching: innovative and traditional practices. Educational Studies, 45(3), 342-356.

Jeffrey, B., \& Craft, A. (2010). Teaching creatively and teaching for creativity: distinctions and relationships. Educational Studies, 30(1), 77-87.

Kazemia, M., Katiraeib S., \& Rasekh. (2014). The impact of teaching lexical bundles on improving Iranian EFL students' writing skill. Procedia - Social and Behavioral Sciences, 98, 864-869.

Kitaygorodskaya, G. A. (1986). Methodical foundations of intensive teaching foreign languages. Moscow: Visshaya Shkola.

Likhachev, O.N. (2017). Features of the formation and consolidation of written speech competence in foreign language classes in non-linguistic universities. Scientific journal KubGAU, 126(2), 1-11. 
Melikhova, I. N. (2018). Foreign language educational program for 03.06.01 "Physics and Astronomy".

Milrud, R.P. (1998). Methods of learning written foreign language speech. FLS, 3, 5-11.

Mirolyubov, A.A. (2011). Methods of teaching foreign languages. M.

Passov, E. I., \& Kuznetsov, E. S. (2000). Learning to write: study guide - Voronezh: Interlingva.

Passov, E. I. (1985). Communicative method of teaching foreign language speaking. M.: Enlightenment.

Cullen, P., French, A., \& Jakeman, V. (2014). The official Cambridge guide to IELTS for academic and general training. Cambridge, UK: Cambridge University Press.

Ratminingsih, N. M., Marhaeni, A. A. I. N., \& Vigayanti, L. P. D. (2018). Selfassessment: The effect on students' independence and writing competence. International Journal of Instruction, 11(3), 277-290. https://doi.org/10.12973/iji.2018.11320a.

Rogova, G.V. (2010). Methods of teaching English language. M., Enlightenment.

Rus, D. (2016). A didactic approach to writing skills in a technical learning environment. Procedia Technology 22, 1191-1196.

Sabanova, L. F. (2007). Formation of professionally oriented speech at an advanced stage of training students of the university. Thes. M.

Sinaga, P., \& Feranie, S. (2017). Enhancing critical thinking skills and writing skills through the variation in non-traditional writing task. International Journal of Instruction, 10(2), 69-84. https://doi.org/10.12973/iji.2017.1025a.

Skorobogatova, A. S. (2017). Foreign language educational program for 19.04.04 "Innovative technologies in production".

Smirnova, E. V. (2015). Actual aspects of improving foreign language writing when using information and communication technology. Baltic Humanitarian Journal, 4(13), 102-104.

Solovova, E. N. (2002). Methods of teaching foreign languages: Basic lecture course. Moscow: Peosvecheniye.

Sysoev P. V., \& Evstigneev M. N. (2010). Methods of teaching foreign language using new information and communication technologies. $\mathrm{M}$.

Ter-Minasova, S. G., \& Kurasovskaya, J. B. (2011). English academic competition for schoolchildren. Moscow: Guideline.

Thoonen, E. E. J., Sleegers, P., Peetsma, T., \& Oort F. J. (2011). Can teachers motivate students to learn? Educational Studies, 37(3), 345-360.

Uçara, S., \& Yazıcı, Y. (2016). The impact of portfolios on enhancing writing skills in ESP classes. Procedia - Social and Behavioral Sciences, 232, 226-233. 
Vishnyakova, S.M. (1999). Professional education. Vocabulary. Key concepts and terms. Moscow: Nov.

Wang, S., Gorbunova, N. V., Masalimova, A. R., Bírová, J., \& Sergeeva, M. G. (2018). Formation of academic mobility of future foreign language teachers by means of media education technologies. Eurasia Journal of Mathematics, Science and Technology Education, 14(3), 959-976.

Vassilaki, E. (2017). Reflective writing, reflecting on identities: The construction of writer identity in student teachers' reflections. Linguistics and Education, 42, 43-52.

Chernukhina, T. B., \& Chernukhin, A. Yu. (2015). Academic essay as a component of communicative foreign language competence: theoretical and methodological aspects. Social Sciences, 3, 113-115.

Chuikova, E. S. (2005). Teaching social and cultural peculiarities of foreign language written speech of students of the faculty of foreign languages. (based on a discursive essay) this. Samara. 